\title{
The Re-education and Future of those Blinded in the War
}

A meeting of the Paris Ophthalmological Society on May 7, 1917, was devoted to discussing various points connected with those blinded in the war. Among other questions taken up by the meeting were the re-education and future of the blinded, nightblindness in soldiers, disorders of sight caused by cranial traumatisms, the improvement of ocular stumps in view of the wearing of an artificial eye, and the ocular signs of death.

Cosse, speaking of the re-education of those blinded in war, said it was but natural at first to follow the experience gained from those blinded in other ways. In that way reading and writing in Braille and the trades taught, including brush-, chair-, and basket-making, came to be adopted. The cleverness shown by the military blind, as well as their rapid progress, led to their employment in other capacities, and also permitted them to take up their former trade or profession and to live in their old residences. The blinded soldier had much to learn-how to walk and to guide himself and sometimes even how to eat. He was taught to read, write, and calculate in Braille, and in order to facilitate his relations with the sighted, he was also taught different ways of writing in black and even typewriting. - His amusements were provided for by teaching him singing, music, cards, dominoes, and physical exercises. Certain trades which would be found useful in some regions, could be taught to the blind. Such employments were rope-making, cooperage, the making of straw-matting or of pearl tiaras, the polishing of glass stoppers, and so forth. Some kinds of agriculture, gardening, and the rearing of chickens had been taught to the blind. Special agricultural schools had been established, as, for example, the one at Sept-Fond.

Petit spoke of the necessity of sympathy between the blinded and the ophthalmic surgeon. Cantonnet described a method of writing for the blind which supplemented without superseding the Braille writing. Lagrange advocated an increased pension to those blinded in war rather than the indiscriminate bestowal of the Military Medal. Roche, who spoke somewhat pessimistically of the future of the blind, recommended organization. Vacher struck an essentially human note when he spoke of the necessity of visiting the military blinded in their homes. Cosse had observed mental disturbance in men both of whose eyes had been enucleated.

A conference was held in Paris from May 8 to May 12 last dealing with the war cripple. The meeting was divided into several sections, of which one was specially concerned with the difficulties of the blind, the deaf, and so on. Among the measures discussed and voted upon were the re-education and the return home of the blind soldier. It was proposed to carry out the treatment of the 
blind as far as possible on the lines laid down by Saint Louis when he founded the Hospice des Quinze-Vingts, and allowed the blind beggars to live there with their families. The Conference advised that husbands and wives were not to be separated, but lodgings were to be found for them near their work.

\section{Night-Blindness}

At the meeting of the Paris Ophthalmological Society, Landolt distinguished between those who suffered from deficient vision at night prior to the war and those who were rendered nightblind as the result of the war. Among the night-blindness revealed by the war there was one group of cases, which he called nocturnal amblyopia, or false hemeralopia, made up for the most part of uncorrected, or badly corrected, ametropia, and of men affected with corneal lesions. A second group, true hemeralopia, included men with choroido-retinal lesions and some rare cases of retinitis pigmentosa, choroiditis, congenital affections of the neuro-retinal system, and of congenital night-blindness, probably physiological. The defect in the first group could be corrected by glasses, and the men kept at the front. In the second group some of the individuals concerned must be put on one side : for example, cases of pigmentary retinitis; some should be drafted into the auxiliary services, as those who combined poor sight with night-blindness; but most of them whose condition was congenital and definitive should be kept at the front, care being taken to notify their condition to the commanding officer. With regard to those rendered night-blind as the result of the war, the cases were very rare, but the condition should be easily cured. Symptoms may disappear after eight or ten days' rest and a suitable diet, including a couple of eggs a day. Cod liver oil, potassium iodide, strychnin, iron, and arsenic, have all been recommended. Fraenkel recommended Förster's photometer for detecting the simulation of night-blindness.

\section{The Support of Artificial Eyes}

Terrien believed that natural stumps, such as atrophic eyeballs, posterior segments, and the sclera retracted as the result of evisceration, are best fitted to bear an artificial eye. But they, as well as an optico-ciliary neurotomy, may be followed by sympathetic ophthalmitis. Enucleation should be completed by grafting into the capsule of Tenon a piece of costal cartilage and by suture of the recti muscles, previously detached from their insertions. $\mathrm{He}$ claimed that there was no danger of sympathetic ophthalmitis after this intervention. The prothesis after an ordinary enucleation might be improved by certain mechanical devices. Contracted sockets should be treated by progressive dilatation. Coulomb 
admitted his preference for an eyeball shrunken to a quarter of its original size as a support for the artificial eye. Sourdille had had a case of sympathetic ophthalmitis after ablation of the anterior segment of the eyeball. In his opinion, exenteration should be reserved for recent wounds. He often inserted a graft of fat under the conjunctiva, sutured en bourse. Dor, in 22 patients who had lost one eye and complained of ocular irritation, found that among these cases the eye had been eviscerated in 21 and enucleated in 1 . On the strength of these figures, he concluded that evisceration was less favourable than enucleation. Vacher thought that too many enucleations were done at the front, and that the cases might well wait some days. Magitot, when operating under unfavourable conditions, undertook in two stages the grafting of cartilage prepared in formol. Even under good conditions, the graft succeeded in only 60 per cent. of the cases. The grafting of a rabbit's eye had yielded Lagrange durable results. Kalt protested against plugging of the orbit after enucleation.

\section{Ocular Signs of Death}

Terson described the ocular signs, early and late, of death. The functional state of the pupils was very variable. Light acted slowly upon them for several hours after death, a remark that applied also to atropin and physostigmin. Electricity sometimes contracted the pupil five or six hours after death. As to the ophthalmo-reactions which involved the circulation, even injections of fluorescein did not always colour the human eye in the living. Cauterization, scraping (raclage), applications of copper sulphate, and subconjunctival injections of saline produced no redness in the still warm body, say, two hours after supposed death. Instillations of ether may be dangerous. Terson preferred to apply dionin, and if the application be made two hours after death no reaction followed.

These reactions may be of importance in cases of apparent death before rigidity or decomposition of the body has supervened.

\section{ABSTRACTS}

INJURIES OF THE EYE, ETC., IN WAR

(Second Notice.)

(I) Weekers, L. (Liège). - Night-blindness in soldiers. (Héméralopie chez les soldats.) Arch. d'Ophtal., March-April, I916.

(2) Dantrelle.-Some cases of papillary stasis following war injuries. (De quelques cas de stase papillare consécutive à des blessures de guerre.) Arch. d'Ophtal., May-June, I916. 